\title{
Long continental pollen record from a tropical intermontane basin: Late Pliocene and Pleistocene history from a 540-meter core
}

\begin{abstract}
Long continental records of climatic change are scarce but are of great importance in facilitating the comparison of land-based and ocean-based climatic histories. In the Eastern Cordillera (Cordillera Oriental) of Colombia, the high plain of Bogota represents the bottom of a former lake that occupied a subsiding intermontane basin. Here, pollen records have been retrieved from two boreholes known as Funza I and Funza II. These records are the longest high-resolution pollen records in the world, as they represent the period from the late Pliocene to the latest Pleistocene. They show the warm late Pliocene climate, direct biogeographical evidence of the closure of the 1sthmus of Panama, and the well-known ice ages of the last 1 million years.

A comparison between the fission-track zircon-based time control of the pollen record and a high-resolution oxygen-isotope record from the Ocean Drilling Program shows corresponding climatic oscillations. Several other basins in the world have a great potential for reconstructing climatic history, and the need is obvious for an international program for drilling long continental cores. The poor readiness of funding bodies to give support is difficult to explain.
\end{abstract}

\section{Introduction}

Pollen records from bogs and lake sediments are well known for their potential to document the local and (or) regional vegetational and climatic history. Changes in the composition of the vegetation, which reflect climatic change, are documented by the pollen rain that is conserved in slowly accumulating lake sediments. In temperate regions especially, the history of most lakes goes as far back in time as somewhere in the last glacial period. Continuously accumulated lake sediments that have good pollen conservation spanning more than the last glacial period are rare. George Kukla (Lamont-Doherty Geological Observatory, New York, USA) succeeded in collecting several long continental records of paleoclimate in a special volume (Kukla, 1989) that shows much of the current knowledge of land stratigraphers.
Intermontane basins have a favorable position in accumulating sediments, and when their drainage systems are poorly developed. long sequences of sediment infill may have accumulated in the past. Tropical mountains especially seem to be in a favorable position because a change in climatic conditions results mainly in a vertical shift of vegetation belts over the mountain slopes. Thus. the different vegetation belts stay in the vicinity and are registered continuously by their intercepted pollen: it is the relative contribution of each vegetation belt to the totally intercepted pollen rain that forms the basis for the reconstruction of climatic change. In this respect, the climatic conditions in temperate and (sub)tropical arid regions in the world obviously are less favorable for the reconstruction of climatic change: during glacial to interglacial transitions. vegetation belts may shift latitudinally over hundreds of kilometers and may become too far away to be registered properly. This is the case, for example, in north Africa where pollen records from many different places have been pieced together recently in order to reconstruct the subcontinental movements of the Saharan-Sahelian boundary during the last glacial to interglacial transition (for example. see Lézine. 1989).

\section{Colombian-Dutch deep coring projects}

The high plain of Bogotá in the Eastern Cordillera of Colombia (about $2,550 \mathrm{~m}$ in altitude. lat $4^{\circ} 50^{\prime} \mathrm{N}$.. Iong $74^{\circ} 12^{\prime} \mathrm{W}$.) has a remarkable position in this field of research. It represents the bottom of a former lake and covers an area of about $25 \times 45 \mathrm{~km}$ (fig. 1). The high plain is surrounded by mountains that reach $200-700 \mathrm{~m}$ over the altitude of the dry lakebed, and Tequendama Falls serves as an outlet of the basin. which is poorly drained by the Río Bogotá. The unique possibility for the study of the Quaternary in Colombia became clear to Thomas Van der Hammen in the 1950s, when he was working as a palynologist with the Servicio Geológico Nacional in Bogotá. The first pollen record having a series of glacial and interglacial ages came from the 195-m-deep borehole CUX-CUY near the rim of the basin (Van der Hammen and Gonzalez. 1960, 1963, 1964). In the 1970s, deep boreholes were drilled in the center of the sedimentary basin near the village of Funza. where the unconsolidated sediments were expected to reach over $500 \mathrm{~m}$ below the surface. In two stages, undisturbed sediments were collected from 0 to $150 \mathrm{~m}$ and from 140 to $357 \mathrm{~m}$ in depth. Pollen analysis took 5 years, and many unknown pollen types appeared on the scene. After 1.230 samples were analyzed, the results were graphed (Hooghiemstra, 1984, 1989) and created one of the largest pollen diagrams ever published. The timeframe of this Funza I record was provided by both potassium-argon dating and fission-track dating on glass from intercalated volcanic ash horizons. Although absolute dating results were of moderate to poor quality, regression analysis of the accepted data provided ages that seemed plausible when comparing this pollen record with the European climatic stratigraphy of the Quaternary. The first long 


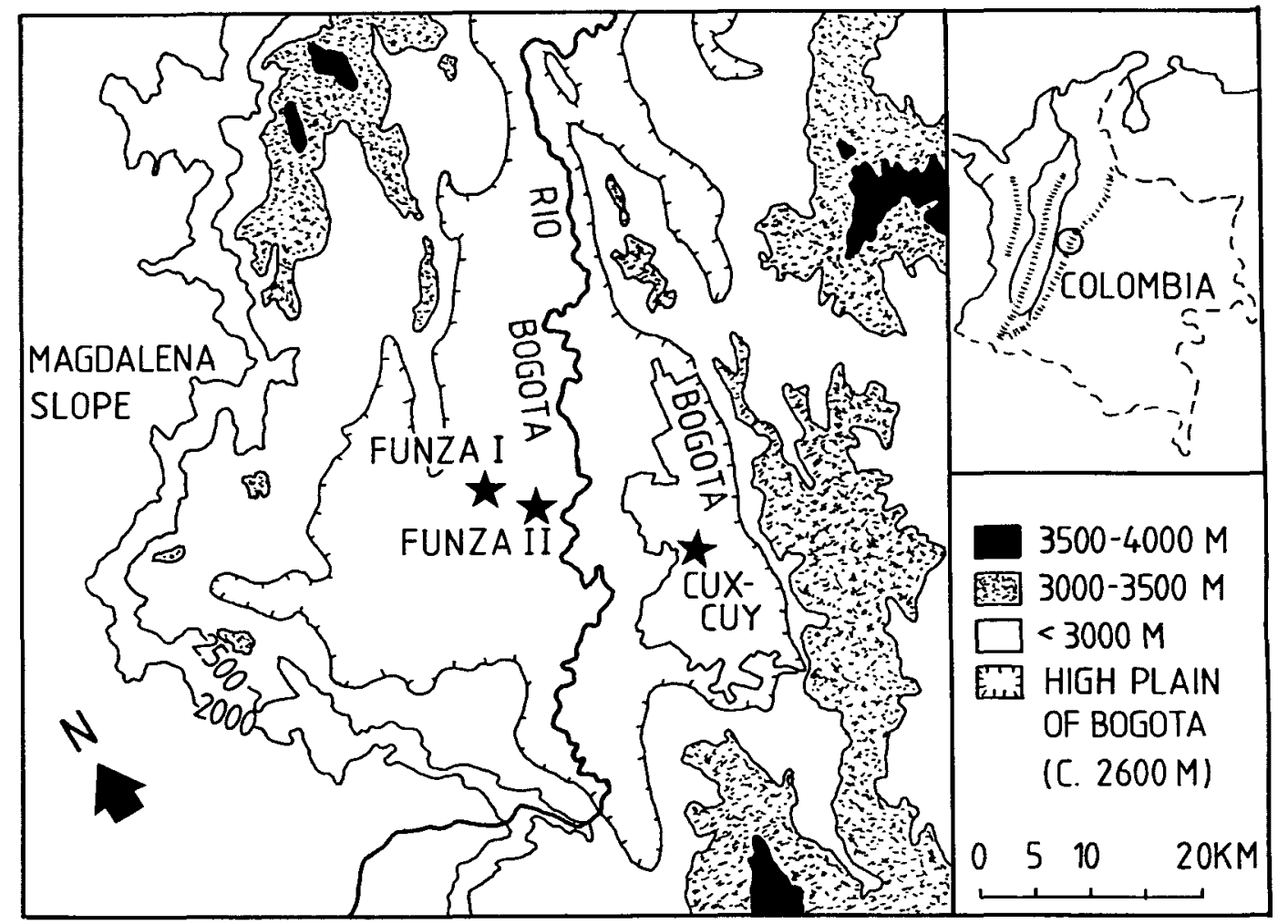

Figure 1.-Location of the main pollen records in the high plain of Bogotá, Eastern Cordillera of Colombia, including Funza I (357 m), Funza II (586 m), and CUX-CUY (195 m) cores.

interval of cold conditions appeared at about 2.5-2.2 Ma, a date that could correspond very well with the Praetiglian Age of about the same time in Europe. In 1988 several conditions necessary for a new, deep, and purely scientific coring program became favorable. Close to the site of Funza I. a new 586-m-deep core was drilled and is referred to as the Funza II core (fig. 2). The deepest $15 \mathrm{~cm}$ of the core consists of sandstone, which suggests that perhaps the floor of the basin (Cretaceous and Tertiary bedrock) has been reached.

The objective of this paper is first to show the results of the pollen analysis of the Funza II core. Then, preliminary results are reported from an experimental correlation between the Funza I pollen record and the high-resolution oxygen-isotope record of Ocean Drilling Program (ODP) Site 677 prepared by Nick Shackleton. The latter indicates a promising way of correlating land-based and ocean-based records of paleoclimate (Shackleton and others, 1990).

\section{Reassessment of time control of basin infill}

The volcanic ash horizons intercalated in the Funza II sediments were dated by the fission-track method on zircon by P.A.M. Andriessen (Laboratory for Isotope Geology. Amsterdam), and they provided data beset with fewer technical problems compared to the data from the Funza I record (P.A.M. Andriessen, unpublished data). Ages of $2.74 \pm 0.63 \mathrm{Ma}$ (506-m depth), $1.01 \pm 0.21 \mathrm{Ma}(322-\mathrm{m}$ depth), $1.18 \pm 0.29 \mathrm{Ma}(319-\mathrm{m}$ depth), and $1.02 \pm 0.23 \mathrm{Ma}$ (interval $307-298-\mathrm{m}$ depth) indicate that the first long-lasting cold period in the Funza records $(233-208-\mathrm{m}$ interval in Funza $\mathrm{I}$, as well as in
Funza II) has an age of about $0.8 \mathrm{Ma}$. Thus, this interval does not correspond to the Praetiglian Age of the European climatic subdivision as reported in Hooghiemstra $(1984,1989)$ for the Funza I record, but it does correspond to the first cold epoch in the deep-sea record (oxygen-isotope stage 22 in Pacific Core V28-239; Shackleton and Opdyke, 1976). This interval follows a significant change in the character of the climatic cycles, when the cycles changed from high-frequency, low-amplitude oscillations in the early Pleistocene to low-frequency, high-amplitude oscillations in the middle and late Pleistocene.

The study of the Neogene to Quaternary chronology and geology of the basin of Bogotá has made much progress in recent years (Helmens, 1990; P.A.M. Andriessen, K.F. Helmens, H. Hooghiemstra, P.A. Riezebos, and T. Van der Hammen, unpublished data). While waiting for the latest dates, we started to study different aspects of the Pleistocene climatic change, such as frequency analysis of climatic oscillations, by using the Funza pollen records (H. Hooghiemstra and J.L. Melice, unpublished data).

\section{Reading the pollen records}

The pollen rain that fell into the former lake of Bogotá was provided principally by the vegetation on the surrounding mountains, which rise up to $3.000-3.200 \mathrm{~m}$ in the near vicinity $(20-25 \mathrm{~km})$ and to $3,600-3,800 \mathrm{~m}$ in the more distant mountain chains $(35-40 \mathrm{~km})$. Accordingly, high percentages of arboreal pollen indicate that the surrounding slopes were entirely or almost entirely covered with forest. Increasing percentages of elements of open equatorial alpine vegetation (páramo vegetation) correspond with a progressively 


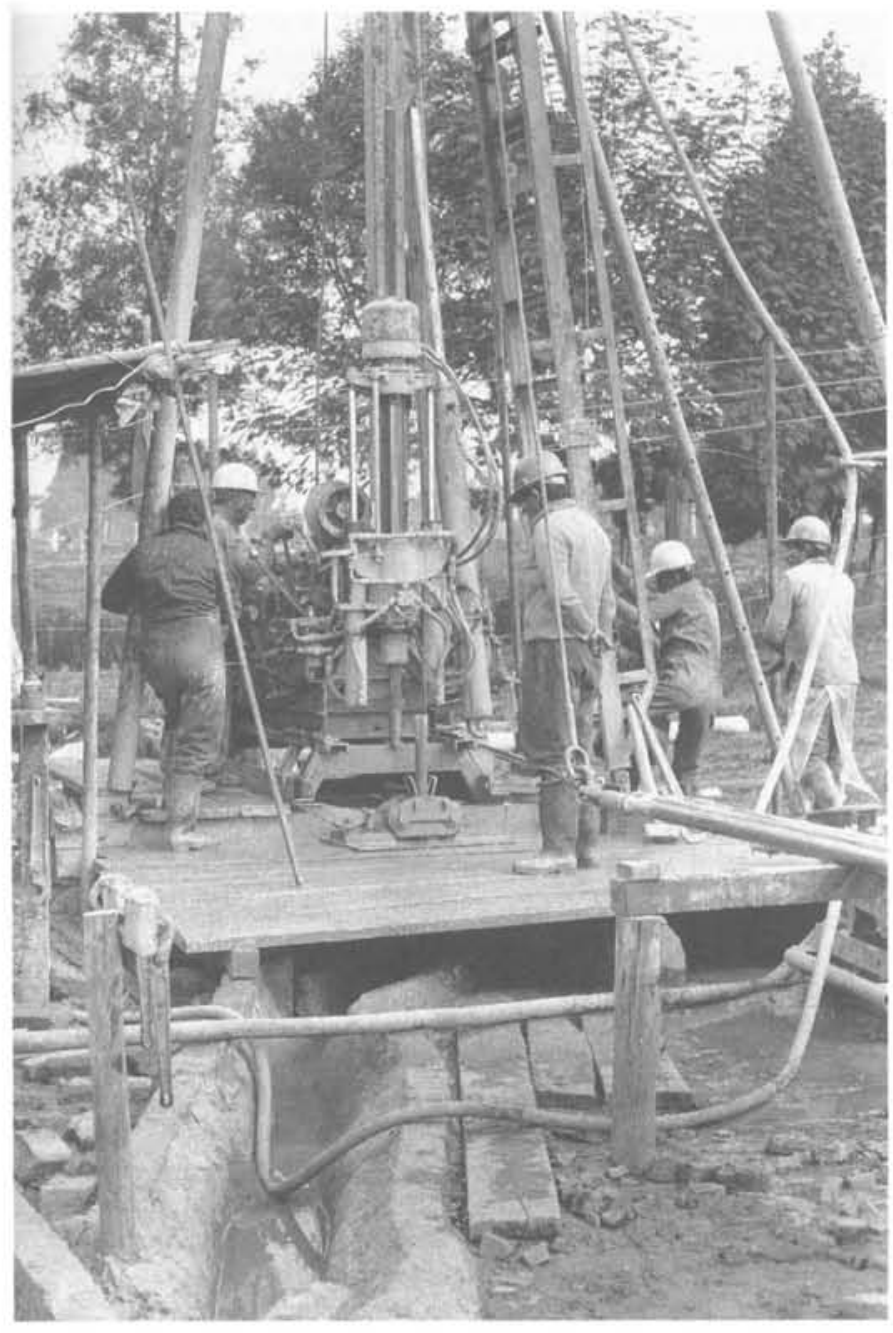

Figure 2.-Drilling equipment of INGEOMINAS in action in the high plain of Bogotá near the village of Funza.

downward shift of the upper forest line. Although climatic humidity has some influence on the altitude of the forest line (actually corresponding to an average annual temperature of $9.5^{\circ} \mathrm{C}$ ), it seems that the main determining factor that controls the altitude of the forest line is the prevailing average temperature. On the basis of studies concerning the relationship between the altitude of the forest line and the proportion of arboreal pollen in modern pollen rain, it was possible to convert arboreal pollen percentages into altitudinal forest-line positions and, subsequently, into estimated average annual temperatures. Because this relationship has been deduced from modern conditions (Van der Hammen and Gonzalez, 1960; Grabandt, 1980, 1985; Melief, 1985, 1989), corrections are necessary either when the composition of the Andean forest changed markedly or when it may be expected that modern ecological relationships are not valid any more. Indeed, the first situation happened when northern hemisphere trees immigrated into South America after the closure of the Isthmus of Panama. First Alnus and later on Quercus arrived in the area of the high plain of Bogotá, and they changed dramatically the composition of the Andean forest. The second situation becomes increasingly important in the lower part of the pollen record of late Pliocene age. After the final upheaval of the Andes (Kroonenberg and others,
1990), the process of adaptation to the newly formed biotopes proceeded for a long time. During this time, the Andean forest belt may not have developed fully and possibly may have been narrower (Van der Hammen, 1974; Hooghiemstra, 1984).

The present vegetation belts in the Eastern Cordillera of Colombia (fig. 3) include tropical lowland vegetation up to about $1,000 \mathrm{~m}$ in altitude (rain forests, savannas, and xerophytic vegetation), the subandean forest belt from $1,000 \mathrm{~m}$ to $2,300-2,500 \mathrm{~m}$ in altitude, and the Andean forest belt from 2,300-2,500 $\mathrm{m}$ to the forest line at $3,200-3,500 \mathrm{~m}$ in altitude. Above the forest line, open alpine vegetation types are present: the subpáramo belt containing scrub and patches of dwarf forest from $3,200-3,500 \mathrm{~m}$ to $3,400-3,600 \mathrm{~m}$ in altitude, the grasspáramo from about $3,500 \mathrm{~m}$ to $4,000-4,100 \mathrm{~m}$ in altitude (having Espeletia as the most characteristic genus), and the superpáramo belt from $4,000-4,100 \mathrm{~m}$ to $4,500 \mathrm{~m}$ in altitude (having incomplete vegetation cover and much frost action in the soil). The subnival zone $(4,500-4,800 \mathrm{~m}$ in altitude) is practically devoid of vegetation. Each of the above mentioned vegetation belts is characterized by the prominence or dominance of many different taxa that can be recognized by their pollen grains. Therefore, each part of the pollen content of a core sample can be attributed to a vegetation belt. Situated at about $2,550 \mathrm{~m}$ in altitude, the former lake of Bogotá received pollen from the subandean forest belt, the Andean forest belt, and the subpáramo, grasspáramo, and superpáramo vegetation belts. The contribution of each belt to the pollen rain is expressed as a percentage of the total, and the first four belts are graphed from left to right, respectively, in the main pollen diagram (fig. 4).

\section{Late Pliocene and Pleistocene development of vegetation and climate}

The late Pliocene Andean forest differed considerably from the modern equivalent. Today's important trees, such as Alnus (alder) and Quercus (oak), had not arrived yet in South America. Both the important contribution of Borreria (originally a savanna element) and the frequently changing abundance of trees that mostly have certain pioneer qualities (Myrica, Eugenia, Miconia, Symplocos, and Rapanea) indicate a more open character for these early Andean (Pliocene) forests (540-465 m interval, about 3-2.4 Ma). On the average, high arboreal percentages are indicative of markedly warmer climatic conditions than those present during the Quaternary interglacial periods. This conclusion is supported by the fact that the Pliocene mountains surrounding the high plain of Bogotá were approximately $200 \mathrm{~m}$ higher (Van der Hammen and Gonzalez, 1960) before the Río Bogotá eroded great amounts of rock during the Quaternary Period and filled the basin, in which subsidence must have been important. Thus, a more extensive area probably was available for Pliocene páramo vegetation, which would have reduced the arboreal pollen percentages, but nevertheless, arboreal pollen percentages reach up to 90 percent. The adaptation of the early Andean forest to high mountain ecological conditions apparently had progressed to almost modern conditions. No strong evidence exists that the forest line was at a much lower altitude at this time. This suggests a much older origin for the Andean forest biome that came into existence after the major upheaval of the northern Andes (Van der Hammen and others, 1973; Kroonenberg and others, 1990). The primitive páramo vegetation was poor in species; apart from the dominant grasses, Compositae (probably mainly representing the woody stem rosettes of the genus Espeletia) and Hypericum scrub were the most important constituents. 


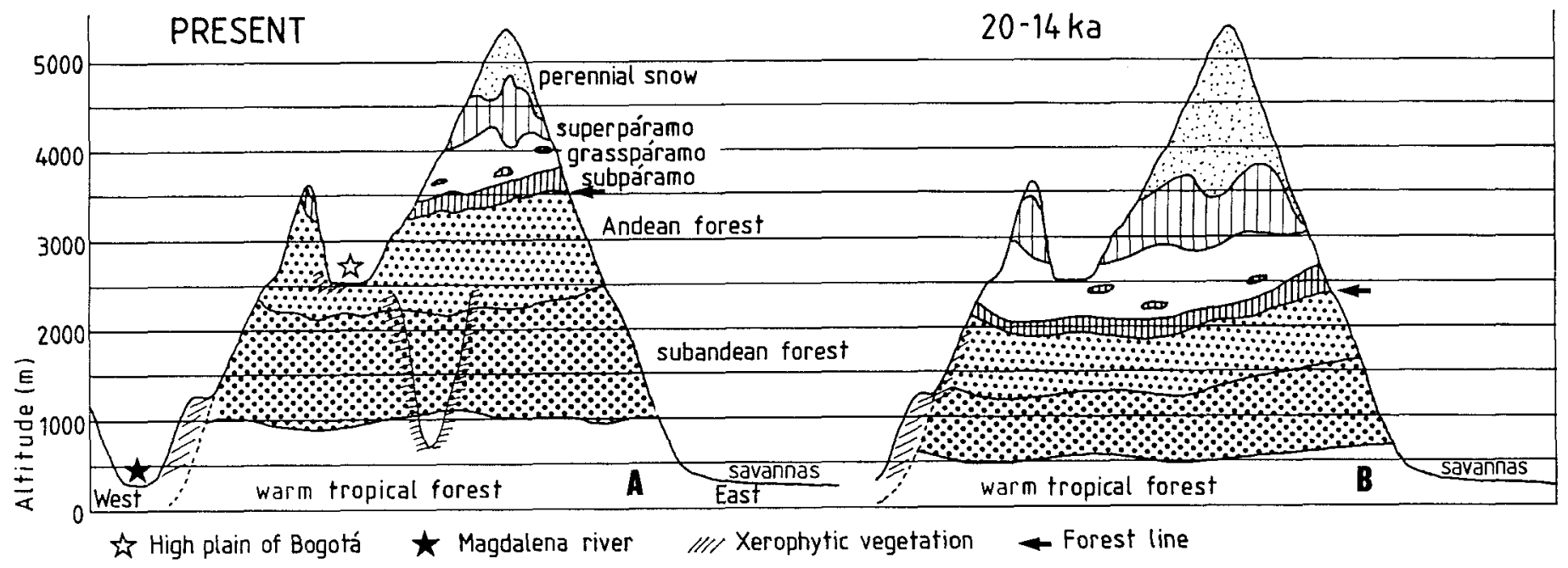

Figure 3.-Altitudinal distribution of vegetation belts in the Eastern Cordillera of Colombia at the latitude of Bogotá in the present (A) and during the last glacial maximum (B). Vertical shifts of the vegetation belts are related mainly to temperature changes during the glacial to interglacial climatic cycles (modified from Van der Hammen, 1974).

At about 2.4 Ma, climatic conditions turned on the average much colder, and the long interval of $465-298 \mathrm{~m}$ in depth in the core of Funza II (about 2.4-1.2 Ma) shows rapidly changing climatic conditions. At this time, the basin of Bogotá must have been continuously in, or very near to, open páramo vegetation that shows an enrichment of taxa: Valeriana, Caryophyllaceae, and Geranium became important elements. Slightly later (at about $400-\mathrm{m}$ depth in the core), Lycopodium, Aragoa, and Plantago also became more important, and near the forest line, Hypericum scrub replaced for a part the Compositae and Myrica scrub ( $M$. parvifolia, a specialized species at the tropical Andean forest line). The lake must have been of a shallow type, as most of the time, aquatic elements of shallow water (Cyperaceae, Myriophyllum, and Polygonum) dominated. However, during several short intervals when the aquatic fern Isöetes indicates deeper water conditions, the shallow-water plants diminished indeed. Frequently, pure sands, sandy clays, and a great number of lignite horizons (fossil peat bogs) were intercalated in the lake sediments. Periodically, the Rio Bogotá supplied large amounts of coarse material to the basin from the surrounding mountains.

Around $300 \mathrm{~m}$ in depth in the Funza cores (about $1.2 \mathrm{Ma}$ ), a change took place in the aquatic conditions. The aquatic fern Isöetes, as well as the algae Botryococcus and Coelastrum, increased markedly in importance, and shallow-water aquatic plants diminished. The lithological column also shows, from this time on, a continuous accumulation of clayey lake sediments, so, apparently, an erosive phase under cold climatic conditions had come to an end. Climatic conditions turned warmer around the 300-m level (pollen zone 44 in the core of Funza I), and warm intervals gradually display higher amplitudes in the pollen records. The composition of the Andean forests did not show a response to this climatic improvement, but at $257-\mathrm{m}$ depth in both Funza cores, a dramatic change took place.

The northern hemisphere tree Almus (alder), which had passed the recently formed Isthmus of Panama, arrived suddenly in the area of Bogotá at 257-m depth at about $1 \mathrm{Ma}$. Alnus acuminata occupied especially the flats around the lake of Bogotá to form swamp forest (carr). and it became a direct competitor of Myrica parvifolia, which decreased in representation. Although Alnus also took part as an element of the Andean forests on the mountain slopes, the prevalence of Alnus was to play a role in the swamp forests around the lake.
Because Alnus does not occur above the forest line, this new element in the pollen record contributed considerably in sharpening the boundary between intervals with low and high altitudinal positions of the forest line (glacial and interglacial intervals, respectively). Around $1-0.8 \mathrm{Ma}$, the cold-resistant and semideciduous Vallea stipularis forests of the Pliocene made way for Weinmannia forests, which apparently had become adapted to higher altitude conditions. But on the mountain slopes, Alnus, in its turn, apparently replaced a part of the Weinmannia forests. Shortly after the immigration of Alnus (at about $1 \mathrm{Ma}$ ), the climatic oscillations became longer and of greater amplitude, a well-known characteristic of the middle and late Pleistocene climatic cycles, as registered in deep-sea cores. The interval of 233 to $208 \mathrm{~m}$ in depth (in both Funza records) represents the first long and cold episode of a series that characterizes the remaining part of the pollen record. It is very plausible that this interval represents stage 22 of the deep-sea oxygen-isotope record (stage 22 in Shackleton and Opdyke (1976), which more recently has been revised into stages 22.23 , and 24 , according to Shackleton (oral communication)).

The upper $230 \mathrm{~m}$ of the Funza records shows some 10 major climatic cycles. The forest line shifted between approximately 3,400 $\mathrm{m}$ and $1,800 \mathrm{~m}$ in altitude, which made the $2,550-\mathrm{m}$ altitude of the high plain of Bogotá a sensitive recorder of the changing climate. Temperature fluctuations from about 6 to $15^{\circ} \mathrm{C}$ have been deduced. At a depth of $92 \mathrm{~m}$ (about $340 \mathrm{ka}$ ), the pollen record again shows the immigration of an important northern hemisphere element. Here, Quercus (oak) starts a continuous record and gradually becomes one of the most important elements of the modern Andean forest on the slopes of the Magdalena valley. All palynologically recognizable elements of the modern Andean forest were present from that time on. The last glacial-interglacial cycle is represented in the record by $40-50 \mathrm{~m}$ of sediments, which indicates that the Río Bogotá supplied extremely high amounts of sediment to the basin. Even coarse gravel was intercalated in the Funza 1 sediments between $34 \mathrm{~m}$ and $6 \mathrm{~m}$ in depth. During this erosive interval, the outlet of the Río Bogotá (Tequendama Falls) probably eroded so far down that the lake of Bogota drained and the accumulation of sediments came to an end at about 30-26 ka. 
Figure 4. - Main pollen diagrams of the cores Funza I and Funza II. The changing contribution of subandean forest and Andean forest taxa indicate the altitudinally shifting position of the forest line, which in turn reflects temperature change. Estimated age (based on Funza II time control), core depth, and pollen zones (Funza I only, taken from Hooghiemstra, 1984, 1989) are shown. Tentative positions given for oxygen-isotope stages 5 through 27 are based on an experimental correlation between the oxygen-isotope record of ODP Site 677 and the pollen record of Funza I. The smaller numbers in the pollen diagram of Funza II (numbered 36 through 54) indicate tentative positions of correlated Funza I pollen zones.

FUNZA II

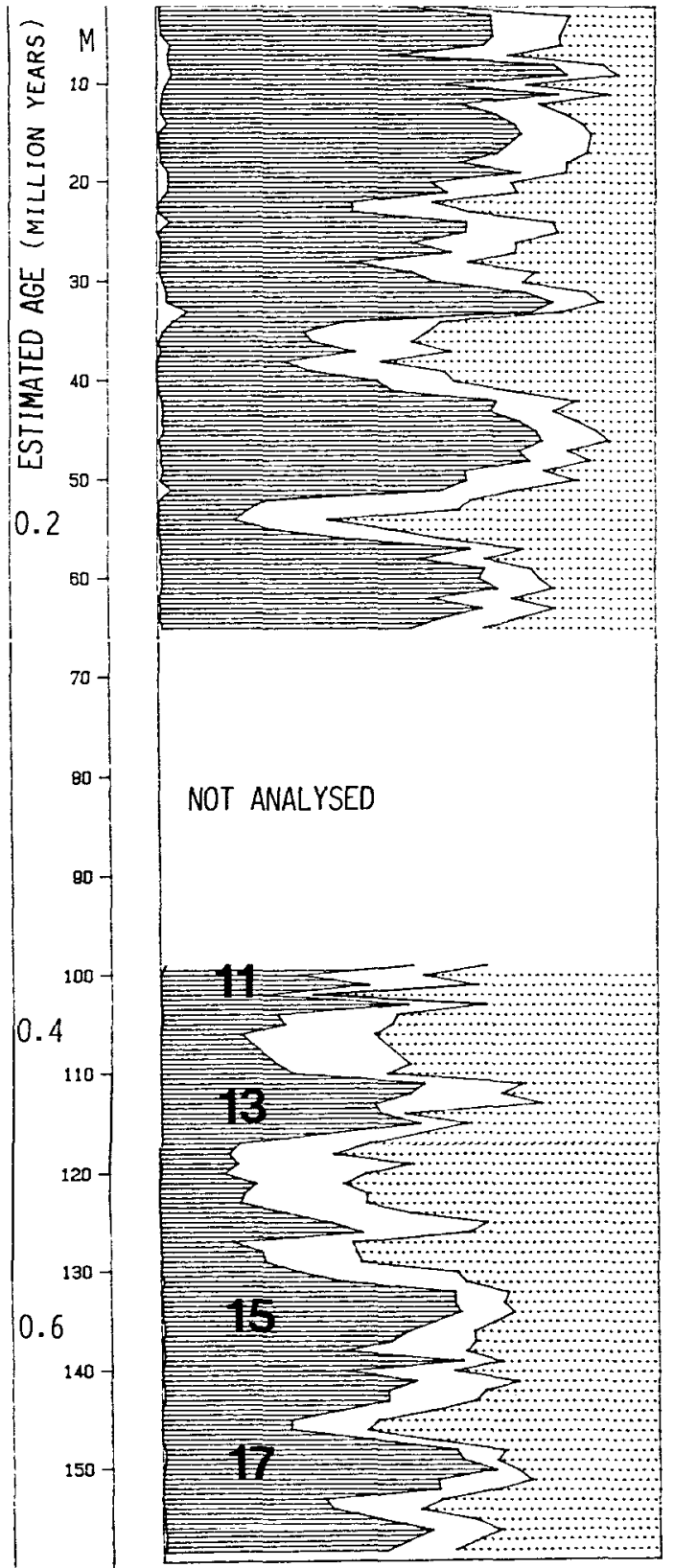

FUNZA I

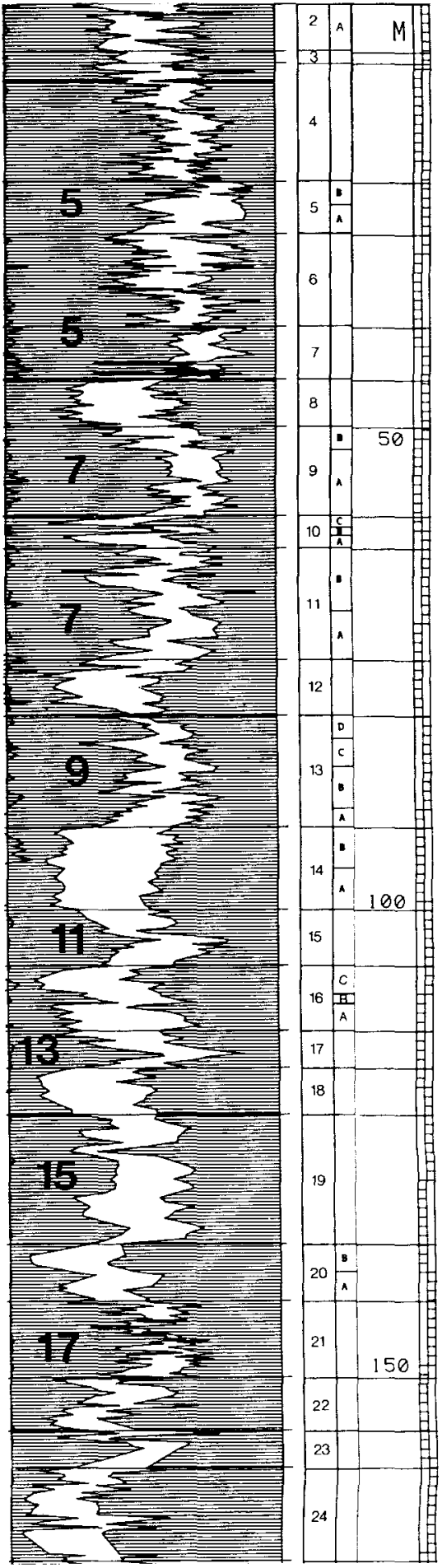



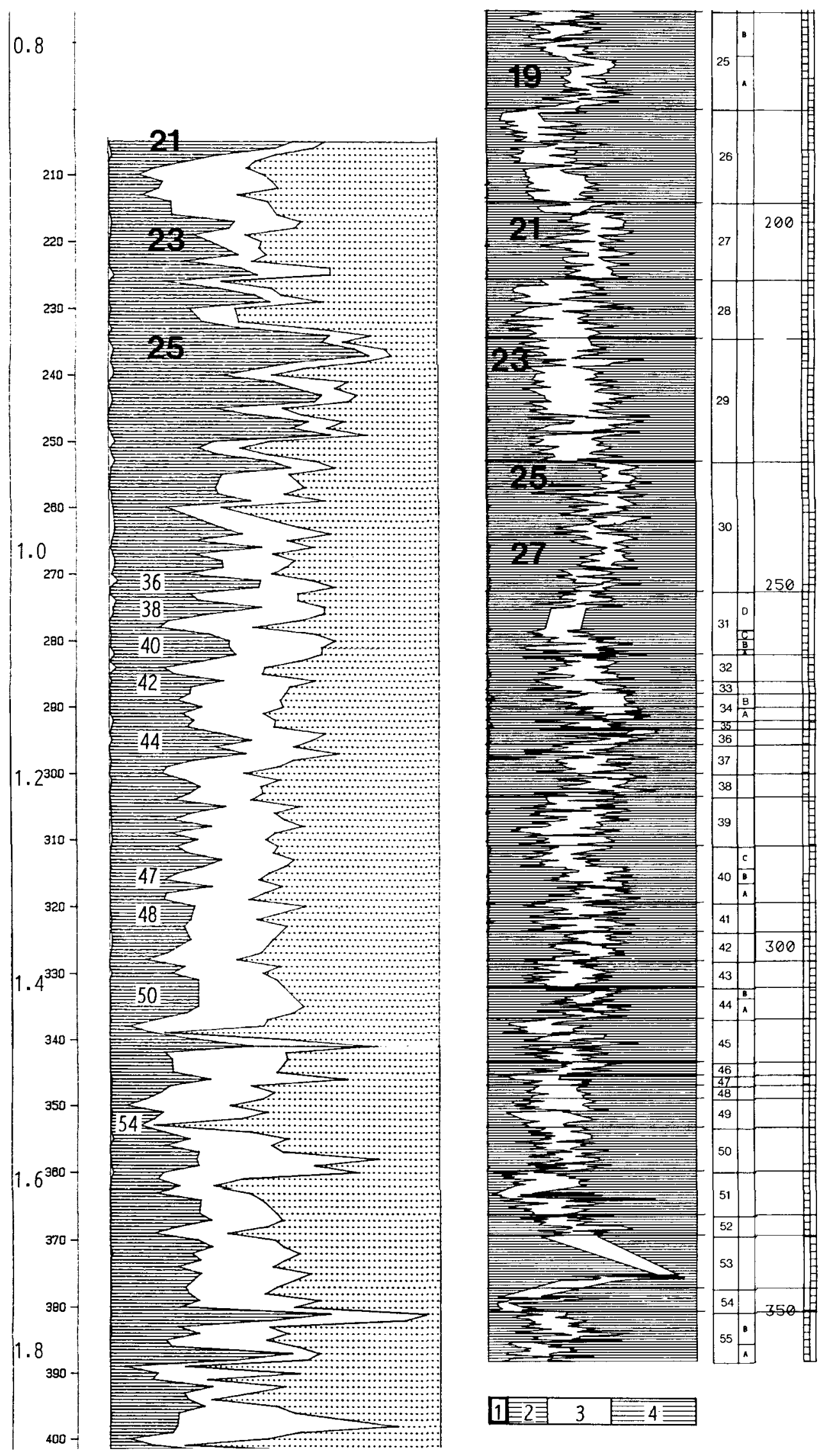


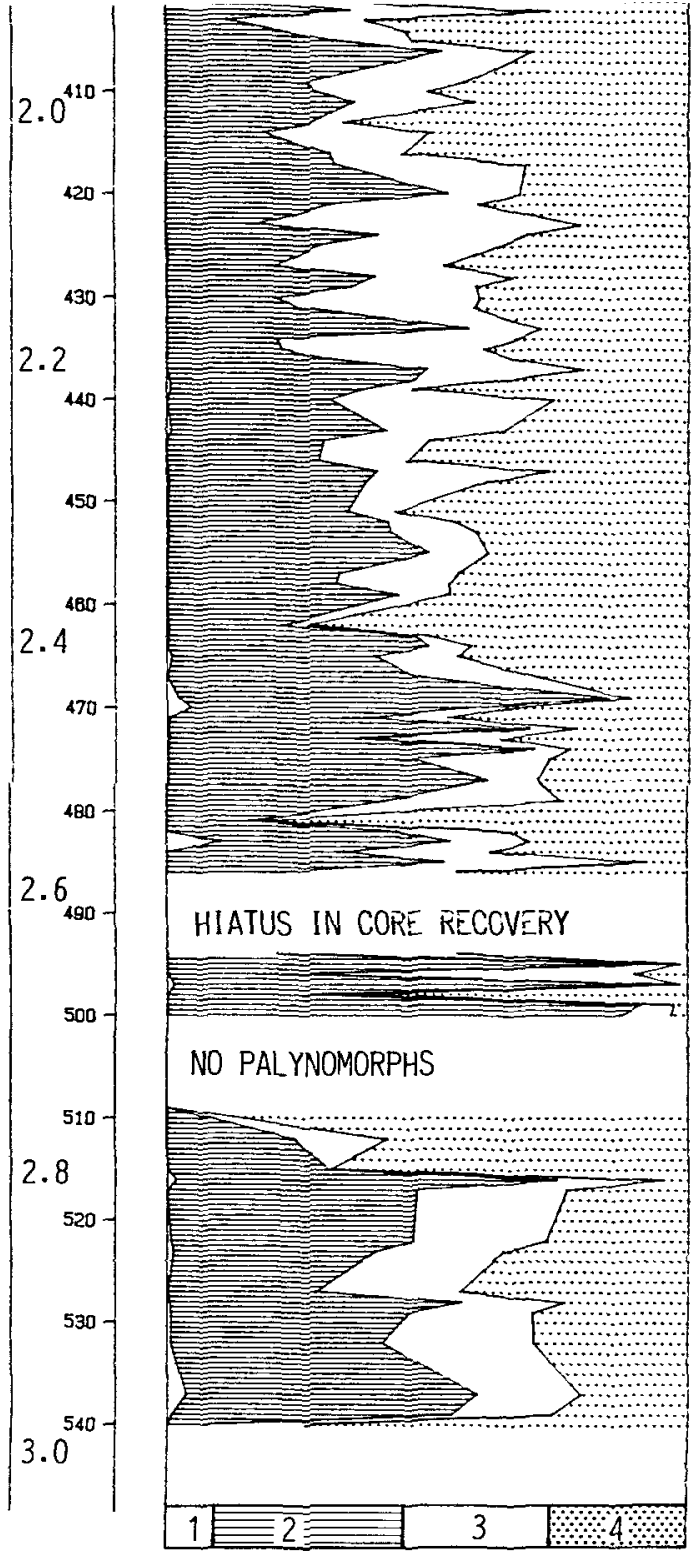

1. SUBANDEAN FOREST TAXA

2. ANDEAN FOREST TAXA

-...- FOREST LINE -...-

3. SUBPARAMO TAXA

4. GRASSPARAMO TAXA

\section{Land-sea correlation experiment}

The recently established timeframe of the Funza 1 and Funza Il pollen records has resulted in a challenging similarity between the climatic fluctuations registered in Colombia and those in the general deep-sea record of paleoclimate. Nick Shackleton of Cambridge University, UK, has been working with the high-resolution oxygenisotope record of ODP Site 677 (Shackleton and others, 1990) from the eastern Pacific Ocean, and we have tried to correlate both records. The pollen record of Funza I was stretched or compressed over many short intervals in such a way that the oscillations of the pollen record run as parallel as possible with the oxygen-isotope curve (N.J. Shackleton and H. Hooghiemstra, unpublished data). After several experiments, 36 control points were established that are assumed to be of the same age (table 1, fig. 5). When we graph the calculated accumulation rates of all 35 intervals between the control points, some control is possible in order to prevent unrealistic accumulation rates with respect to the properties of the sedimentary column. The intervals represented by stages 3 through 25 show the best correlation between climatic oscillations, but stage 16 especially needs more detail in the pollen record. Future analysis of the new Funza II core to the same degree of resolution (sample distance of 20 $\mathrm{cm}$ ) will provide a second opportunity to carry out this experiment, and we expect that it will be possible to arrive at an acceptable land-sea correlation of climatic change for the last 2.5 million years.

\section{Acknowledgments}

Financial support by COLCIEnCIAS (Bogotá), the Netherlands Foundation for Scientific Research. The Hague (grant H 75-284), the Instituto Nacional de Investigaciones Geológico-Mineras (INGEOMINAS, Bogota), and the Hugo de Vries-laboratory, University of Amsterdam, made this purely scientific boring possible. Professor Thomas Van der Hammen is thanked for stimulating the Funza 11 coring project. INGEOMINAS made available a wide range of equipment, as well as logistic and technical support. Dr. A Castro-N. and Dr. C. Guerrero of Smith International Company (Bogotá) made many fishing instruments available when broken coring rods had to be recovered. Dr. E.T.H. Ran joined the Funza project in 1989. Mrs. E. Beglinger and Mrs. A. Philip prepared the pollen samples. Dr. Nick Shackleton is acknowledged for making available unpublished data and for performing the correlation experiment using the ODP core.

Table 1.-Age control points in the experimental correlation between the Funza I pollen record and the ODP Site 677 oxygenisotope record (N.J. Shackleton and H. Hooghiemstra, unpublished data)

\begin{tabular}{cc|cc}
\hline Depth, in meters & Age, in ka & Depth, in meters & Age, in ka \\
\hline 2.90 & 30 & 184.40 & 790 \\
20.00 & 59 & 197.40 & 809 \\
22.25 & 71 & 208.80 & 866 \\
43.40 & 128 & 211.40 & 879 \\
49.00 & 186 & 214.00 & 892 \\
74.0 & 245 & 235.00 & 955 \\
81.00 & 287 & 241.00 & 977 \\
92.00 & 339 & 265.60 & 1024 \\
101.00 & 362 & 268.20 & 1052 \\
107.50 & 423 & 271.80 & 1075 \\
114.50 & 478 & 276.80 & 1110 \\
118.00 & 524 & 291.20 & 1178 \\
123.00 & 565 & 302.00 & 1206 \\
137.00 & 620 & 310.00 & 1244 \\
141.60 & 668 & 317.60 & 1318 \\
147.00 & 686 & 331.00 & 1403 \\
161.20 & 720 & 339.80 & 1453 \\
172.40 & 765 & 350.00 & 1529 \\
\hline
\end{tabular}




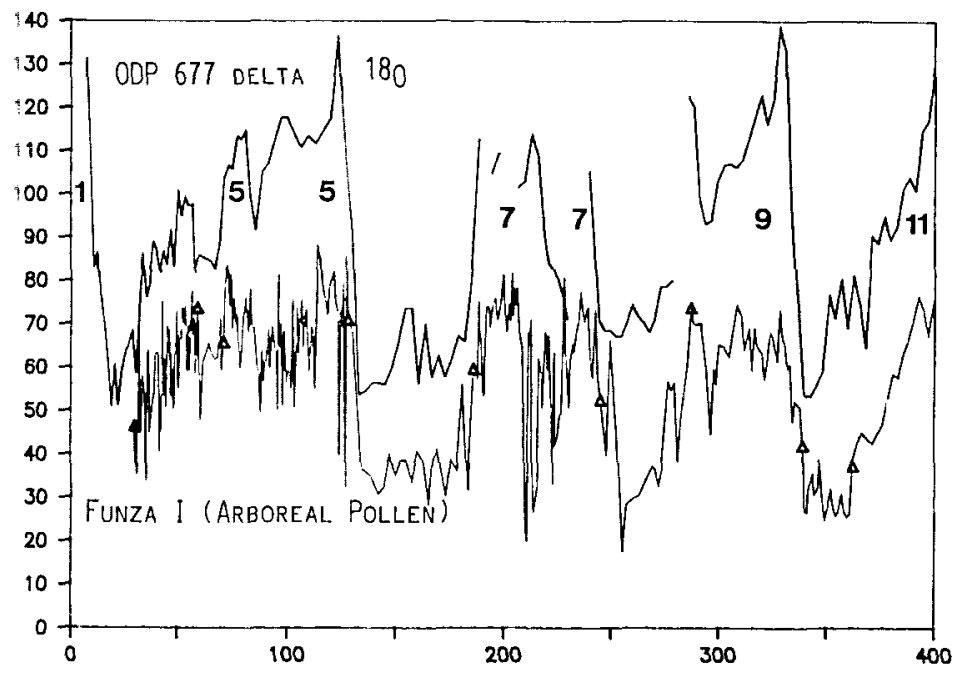

Figure 5.-Experimental visual correlation of the pollen record of Funza I (Hooghiemstra, 1984, 1989) and the oxygen-isotope record of ODP Site 677 (Shackleton and others, 1990). By using the time control of Funza $I$ and ODP Site 677, the intervals representing stage 22 in both records and the core tops were correlated. Subsequently, the pollen record was stretched or compressed over 35 short intervals between 36 control points. The parallel records show the tentative correlation for oxygen-isotope stages 3 through 25 (some uncertainty exists at stages 5, 7, and 16). The correlation of oxygen-isotope stages 26 through 35 has to be regarded as experimental (taken from N.J. Shackleton and H. Hooghiemstra, unpublished data).

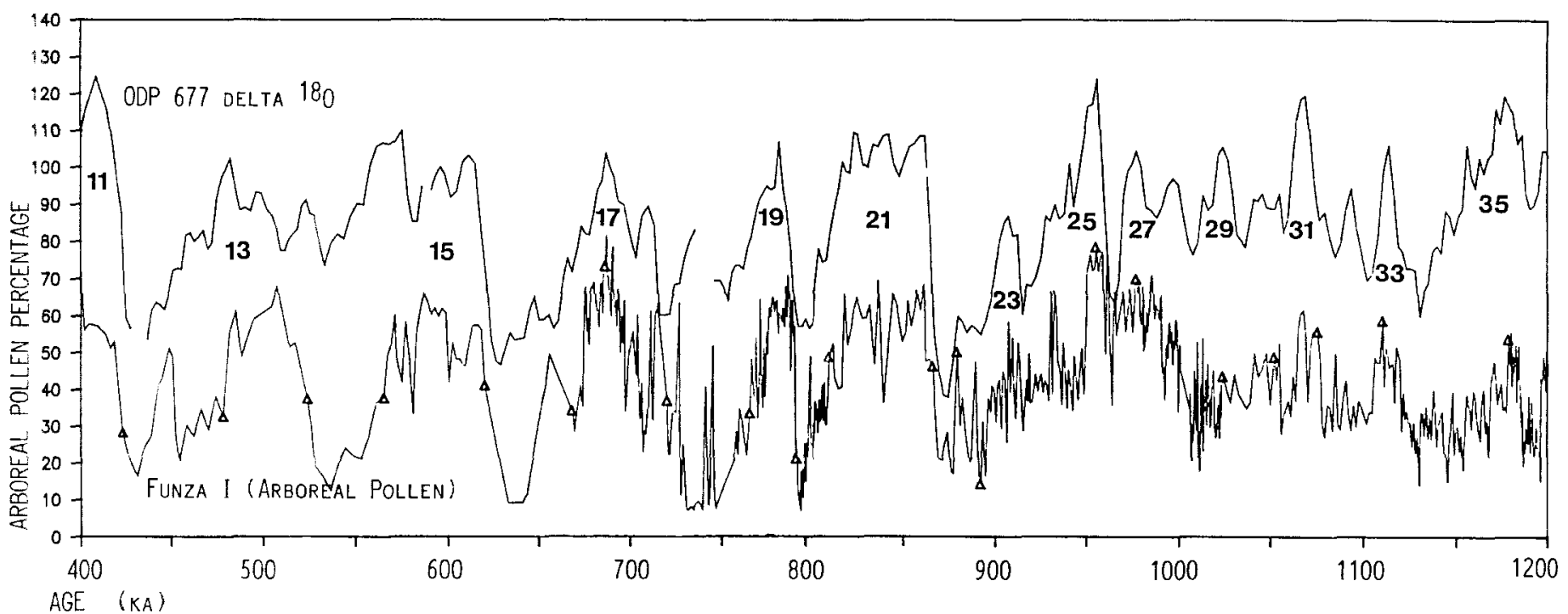

\section{Retierences}

Gratandt. R.A.J., 1980. Pollen rain in relation to arboreal vegetation in the Colombian Cordillera Oriental: Review of Palaeobotany and Palynology, v. 29. p. 65-147.

- - 1985. Pollen rain in relation to vegetation in the Colombian Cordillera Orientat: Amsterdam. University of Amsterdam. Ph.D. thesis. $144 \mathrm{p}$., and published in Van der Hammen, T., ed., The Quaternary of Colombia: Amsterdam, Elsevier Science Publishers, v. 11 .

Heinens. K.F. . 1990, Neogene-Quaternary geology of the high plain of Bogotá (Eastern Cordillera, Colombia): Stratigraphy, paleoenvironments and landscape evolution: Berlin-Stuttgart, J. Cramer, University of Amsterdam. Ph.D. thesis. Dissertaciones Botanicae, v. 163, 202 p.

Hos ghiemstra, H., 1984, Vegetational and climatic history of the high plain of Bogotá. Colombia: A continuous record of the last 3.5 million years: Vaduz, Liechtenstein, J. Cramer, University of Amsterdam, Ph.D. thesis, Dissertaciones Botanicae, v. 79, 368 p.

- - 1989, Quatemary and upper Pliocene glaciations and forest development in the tropical Andes: Evidence from a long high- resolution pollen record from the sedimentary basin of Bogotá, Colombia: Palaeogeography, Palaeoclimatology, Palaeoecology, v. 72 , p. $11-26$.

Kroonenberg, S.B., Bakker, J.G.M., and Van der Wiel, A.M., 1990, Late Cenozoic uplift and paleogeography of the Colombian Andes: Constraints on the development of high-andean biota: Geologic en Mijnbouw, v. 69, p. 279-290.

Kukla, G., 1989, Long continental records of climate-An introduction: Palaeogeography. Palaeoclimatology, Palaeoecology, v. 72, p. 1-9.

Lézine, A.M., 1989, Late Quaternary vegetation and climate of the Sahel: Quaternary Research, v. 32, p. 317-334.

Melief, A.B.M., 1985, Late Quaternary paleoecology of the Parque Nacional Natural los Nevados (Cordillera Central) and Sumapaz. (Cordillera Oriental) areas, Colombia: Amsterdam. University of Amsterdam, Ph.D. thesis, 162 p., and published in Van der Hammen, T., ed.. The Quaternary of Colombia: Amsterdam, Elsevier Science Publishers, v. 12.

1989. Relation of pollen rain and vegetation in the Parque los Nevados transect, in Van der Hammen, T., Diaz-Piedrahita, S., and Julio-Alvarez, V., eds., Studies on tropical Andean ecosystems: BerlinStuttgart. J. Cramer, v. 3, p. 517-536. 
Shackleton. N.J., Berger, A., and Peltier, W.R., 1990, An alternative astronomical calibration of the lower Pleistocene timescale based on ODP Site 677: Transactions of the Royal Society of Edinburgh, Earth Sciences, v. 81 , p. $251-261$.

Shackleton, N.J., and Opdyke, N.D., 1976, Oxygen-isotope and paleomagnetic stratigraphy of Pacific Core V28-239, late Pliocene to latest Pleistocene, in Cline, R.M., and Hays, J.D., eds., Investigation of late Quaternary paleoceanography and paleoclimatology: Geological Society of America Memoir 145, p. 449-464.

Van der Hammen, T.. 1974, The Pleistocene changes of vegetation and climate in tropical South America: Journal of Biogeography, v. I, p. 3-26.

Van der Hammen, T., and Gonzalez, E., 1960, Upper Pleistocene and Holocene climate and vegetation of the Sabana de Bogotá (Colombia, South America): Leidse Geologische Mededelingen v. 25, p. 126-315. 1963. Historia de clima y vegetacion del Pleistoceno superior y del Holoceno de la Sabana de Bogotá: Boletin Geologico (Bogotá), v. 11 , p. $189-266$.

1964, A pollen diagram from the Quaternary of the Sabana de Bogotá (Colombia) and its significance for the geology of the northern Andes: Geologie en Mijnbouw, v. 43, p. 113-117.

Van der Hammen, T.. Werner. J.H., and Van Dommelen, H., 1973, Palynological record of the upheaval of the northern Andes: A study of the Pliocene and lower Quaternary of the Colombian Eastern Cordillera and the early evolution of its high-Andean biota: Review of Palaeobotany and Palynology, v. 16, p. 1-122.

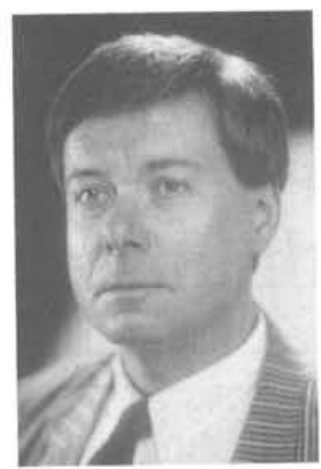

Dr. Henry Hooghiemstra is a paly. nologist in the Department of Palynology and Palaeo/Actuo-Ecology of Amsterdam University (Kruislaan 318, NL-1098 SM Amsterdam, The Netherlands). His interest focuses on Quaternary time in the tropics. Since 1977, he has devoted most of his time to very long cores from Colombia, and the land-sea correlation of paleoclimate has his special interest. From 1983 to 1987, he worked in marine palynology at Göttingen University (FRG), where he studied the history of the Saharan region in Atlantic Ocean cores.

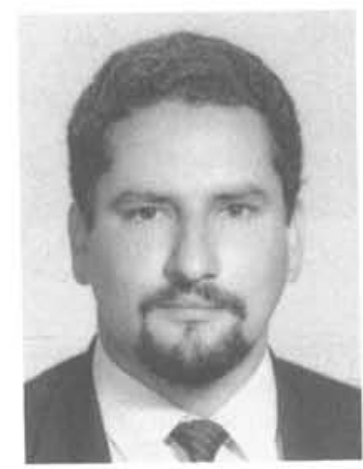

Gustavo Sarmiento is a geologist and palynologist with the Colombian Instituto Nacional de Investigaciones Geológico-Mineras (INGEOMINAS, Diagonal 53 No. 34-53, Bogotá D.E., Colombia). He primarily studies the palynological record along the Cretaceous-Tertiary boundary. His emphasis is on the Maastrichtian and Paleocene and their relationship with the environment. 